\title{
$\checkmark$ Research Square \\ Causation of potential drug to drug interactions alerts, alert overrides, and adverse drug events
}

Aminah Mazyin Mohamed Ariff ( $\Delta$ aminahmazyin@gmail.com )

International Medical University https://orcid.org/0000-0002-2335-2055

\section{Sivalingam Nalliah}

International Medical University

\section{Hafidz Abd Hadi}

International Medical University

\section{Nay Thu Win}

National Heart Institute

Mohamed Imran Thoulath

National Heart Institute

Ahmad Tantawi Jauhari Aktifanus

National Heart Institute

Subashini Muthiah Mutaya

National Heart Institute

Ahmad K. M. Yusof

National Heart Institute

\section{Research Article}

Keywords: Clinical drug decision support system, drug to drug interactions, pharmacovigilance algorithm, adverse drug events, critical cardiac patients

Posted Date: April 9th, 2021

DOl: https://doi.org/10.21203/rs.3.rs-363764/v1

License: (1) (1) This work is licensed under a Creative Commons Attribution 4.0 International License. Read Full License 


\section{Abstract}

Background: Drug-drug interactions (DDIs) leading to adverse drug event (ADEs) are of special interest because they represent preventable medication errors. Preventable ADE can result in errors involving the manifestation of adverse patient outcomes. Given the high complexity of critically ill cardiac patients, it is important to learn how CDDSS affects outcomes in this population and the number of alerts that likely be safely suppressed.

Purpose: Identify adverse DDIs that is clinically detected and review the appropriateness of the doctor's actions to the potential DDIs (PDDIs) alert.

Study Design: This is a prospective observational study conducted at critical cardiac care unit (CCU) in a selected tertiary cardiac center for a duration of six months.

Methods: Physicians treating critically ill cardiac patients were presented with PDDIs data which were acquired from two commercially available CDDSS. The relationship between the decision to prescribe and factors hypothesized to affect physicians' decisions were examined.

Results: Evaluation of 709 patient medication profiles were conducted, resulting in 521 assessed patient profiles having had one or more PDDIs with $87 \%$ of them were influenced by polypharmacy. Ninety-one patients (17.5\%) were associated with one or more adverse DDIs. Of the total 3284 potential DDIs alerts, $95.5 \%$ of the alerts were overridden. Preventable ADE as an outcome of inappropriate override have resulted $83.1 \%$. (236/284) of adverse DDIs. Whereas, appropriate overrides as an outcome of clinically irrelevant ADE were $16.9 \%(48 / 284)$.

Conclusion: Poor preventive actions taken by the doctors caused drug related harm to the patients despite having CDDSS in place. This suggests that CDDSS is an important application to minimize the harm associated with adverse DDIs by alerting physicians of potentially unsafe situations.

\section{Introduction}

Drug to drug interactions (DDIs) leading to adverse drug events (ADEs) are of special interest because they represent preventable medication errors. Prevention of $A D E$ is important not only to reduce morbidity and mortality, but also to improve compliance with medications (1). A review of 27 studies by Zheng WY et al. revealed that $33 \%$ of general patients and $67 \%$ of intensive care patients experienced PDDIs during their hospital stay (2). Although the magnitude of adverse DDIs is concerning, most healthcare providers are not fully aware of the clinically important DDIs, and their threat to the patients $(3,4)$. Implementing computerized physician order entry (CPOE) with clinical decision support system (CDSS) that check for DDIs is one of several basic (Stage 1 and 2) criteria for 'Meaningful Use' by hospitals (5). The Health Information Management Systems Society defines CPOE as an order entry application specifically designed to assist practitioners in creating and managing medical orders including medications (6). CDSS is a software that is designed to be directly aid clinical decision-making. The generation of DDIs alerts is 
one aspect of CDSS, called clinical drug decision support system (CDDSS). CDDSS that alert physicians' prescriptions is a promising tools to prevent medication error which potentially reduces incidence of ADEs by $90 \%(7,8)$. Patients admitted to the critical cardiac care unit (CCU), experiencing ADEs are going undetected. Imperatively, the significance relevant of PDDIs can only be known with the evidence of the ADEs. However, only a few studies have examined clinically important DDIs in CCU settings $(2,9)$. Research using CDDSS can contribute to a better understanding of PDDIs and adverse DDIs and allows the opportunity for prevention and improve the clinical outcomes $(10,11)$. Understanding the mechanism and severity of PDDIs is of utmost importance to the prescriber to avoid the risks of adverse DDIs to the patient (12). Considering the importance of preventing ADE to prevent mortality and morbidity in critical cardiac patients at acute care settings, this study is undertaken to understand the relationship between PDDIs alerts, alert overrides, and ADE.

\section{Methods}

This is a prospective observational study conducted at a CCU in a selected tertiary cardiac center. A data pertaining to 649 critically ill cardiac patients were collected using convenient sampling technique for a duration of six months excluding public holidays and weekends. This met the criteria of 1112 patient-days (95\% confidence level) within the six months of study (8). The profile data of 150 patients were not assessed while sixty patients were not found to have any PDDIs during their admission at CCU. The study included adult patients ( $>18$ years of age) prescribed more than one drug at CCU with maximum length of stay of three days (72 hours). Data were retrieved from patients admitted in CCU covering cardiology but excluded surgical (cardiothoracic) patients, patients admitted to CCU with more than three days or patient sent out for procedures at the point of doing ward rounds. Medications administered once, topical medications or sterile/infusion saline preparation were excluded for PDDIs assessment. An overview of recruitment methodology is illustrated in Fig. 1.

CDDSS can be linked to a CPOE or can be operated as a stand-alone system. In our setting, the institution was not using CPOE for medication orders. The prescription was handwritten by the physician treating the patient. We used two commercially available standalone CDDSS to identify the high severity PDDIs where the entire medications were entered manually. Interactions are considered significant if one or both CDDSS ranked the interaction severity as 'contraindicated/major' or 'moderate' (Supplemental file 1). Minor PDDIs alerts were excluded from the study. PDDIs identified by at least one of the CDDSS, PDDIs severity ratings and the unique interacting drugs and drug classes were recorded. A unique drug pair or unique drug class is a specific combination of interacting medications. Demographic parameters such as patient's sex, age, LOS, and patient disease were recorded as well. PDDIs yielded from both CDDSS were notified to the cardiologists in charge of the patient. The cardiologist then intervene as required. Throughout the manuscript, 'intervention' refers to action taken upon or to prevent an ADE including discontinue medication, change medication, administer antidote or change time interval, frequency, route of administration or dose. An alert override as an alert followed by no change in care when one was recommended (13). DDIs that altered the course of treatment and interventions are measured as clinically relevant adverse DDIs and 'overrode PDDIs alert' was considered inappropriate if the interaction harmed 
the patient (14). The suspected drugs were further assessed for the likelihood of adverse DDIs using a pharmacovigilance algorithm; drug interaction probability scale (DIPS) (15).

\section{Statistical analysis}

A chi-square test was used to compare ADE rate by override appropriateness. Significance of each type of overrides and adherence were calculated using ANOVA analysis.

\section{Results}

Six hundred and forty-nine patients admitted to CCU were included in the study. Of these patients, 449 (69.1\%) were males and 200 (30.8\%) were females. The median age of the admitting patient was 65 years and the median length of stay was 3.0 days (range 1-33 days). High severity alerts (major and moderate) generated by the CDDSS were assessed by the physicians for three consecutive days excluding weekends and public holidays. In total, 4249 PDDIs alerts were found in patients alerted by at least one or both CDDSS (190.4 PDDIs/100 patient days) with 543 of these being the unique drug pairs. Number of PDDIs found for each patient admitted at CCU ranged from 1-43 interactions. PDDIs were not detected in 60 patients during the period of study. On the average, number of PDDIs generated for each patient was 14.0 alerts. Cumulatively, 543 unique drug pairs accounted for only 13\% (543/4249) of the total alerts with 313 unique drug-drug classes (pharmacologic action). Common drug classes triggered were anticoagulants/antiplatelet agents, anti-arrhythmic, anti-diabetic and hypertensive medications. Antiplatelet and antiarrhythmic reacted to 15-20 other drug classes. The antiplatelet - anticoagulant drug class combination was triggered the most, followed by dual antiplatelet, antiplatelet - diuretic, antiplatelet - statins, antiplatelet - antidiabetic, diuretic - proton pump inhibitors, antiplatelet - calcium channel blocker, opioid - benzodiazepine, antiplatelet - angiotensin-converting-enzyme inhibitors and antiarrhythmic class III - diuretic. Overall CDDSS A detected largest number of PDDIs. On the other hand, CDDSS $B$ detected a higher proportion of major alert severity. Of the PDDIs, moderate severity was the most prevalent (24-60\%), followed by major PDDIs (14-46\%). Overall, 201 PDDIs were rated as major interactions by $C D D S S A$ and not identified by $C D D S S B$, and 120 PDDIs were rated as major interactions by $C D D S S B$, and not identified by $C D D S S A$. Statistical analysis confirmed that there was poor agreement between CDDSS $A$ and CDDSS $B$ in identifying PDDIs. Agreement between CDDSS $A$ and CDDSS $B$ coincided in only $36.9 \%$ of the PDDIs, weighted kappa of 0.10 with a $95 \%$ confidence level. There was a total of 4249 alerts generated for prescriptions ordered in 649 patients. The number of 'missed cases' i.e. not assessed were 965 alerts in 128 patients. Reasons being the patient were transferred out from CCU before the ward rounds or no available physicians assessing the patient for the PDDIs. A total of 3284 alerts were screened by 22 cardiologists. Of these 95.5\% (3137/3284) alerts were ignored or overridden. Overridden rate for each category were calculated from the total number of overridden alerts $(n=3137)$ shown in Table 1. While, adherence rates were expressed as the number of adhered alerts divided by the number of total presented alerts. Only 4.5\% (147/3284) from the total alert presented were initially considered relevant by the attending physicians. We observed and categorized accepted/adhered responses into two categories (Table 2). Significance of each type of overrides and adherence were 
calculated using ANOVA analysis. Override and adherence rates to PDDIs alert were compared among patient complexity levels and they were both statistically insignificant with $p$ value $>0.05$. Huge number of PDDIs were ignored and not acted upon by the providers. Top ten drug pairs that was ignored initially, caused ADE and action taken are portrayed in Table 3. The rate of ADEs was higher with inappropriate $(132 / 284)$ vs appropriate overrides (48/284). Total number of clinically relevant ADE was 236 of 284 episodes (83.1\%).

\section{Discussion}

This study confirms the unambiguity of adverse DDIs in critical cardiac patients. This study captured 284 episodes of adverse DDIs in 91 patients. This translates into 17.5\% in 521 patients who suffered one or more adverse DDIs. The occurrence rate is slightly higher compared to other studies. Previous studies have demonstrated that ADE potentiated by DDIs is responsible for up to $11 \%$ of all hospitalized patients (16-18). The present study found a total of 236 clinically relevant adverse DDIs which has two breakdowns. First, inappropriate override by the physicians have resulted 46.5\% (132/284) of adverse DDIs. Second, adverse DDIs were observed before warranting the physicians (before 24 hours) and intervention was undertaken following accepting the PDDIs alert $(104 / 284 ; 36.6 \%)$. Both scenarios are classified as preventable ADEs. The other kind of 'override alerts' when ADE occurred however recommendations were ignored because the risk of subsiding any one of the drugs would decrease the therapeutic effect compared to the consequences of the adverse DDIs (48/284; $16.9 \%)$. This type of scenario is classified as 'appropriate overrides' as an outcome of clinically irrelevant ADE. Physician acknowledging the alert's recommendation before an ADE were mediocre, compared to action taken after an ADE occurred (43:104). It is encouraging to find that over half; $270 / 543$ unique PDDIs shares the same drug to drug class interactions. This finding is in agreement with Nanji et al. findings which showed that alerting PDDIs by drug class was more meaningful than by generic PDDIs in the multidiscipline outpatient practice (19). It can, therefore, be assumed that alerting the physicians on the PDDIs by grouping the drug class would reduce the multiple alerts. A typical example in this study is post-myocardial infarction stenting procedure medications (clopidogrel, aspirin and fondaparinux) which produced three alerts, and each warned about bleeding risk. This seems to 'annoy' the physicians because they were required to respond to each alert individually. Hypothetically, physicians only need to be warned once on the potential risk for anti-platelet-anticoagulant combination.

Alarming only high severity interactions did not reduce the growing exposure of alerts in this study. It is possible to hypothesize that the issue of alert fatigue can be curbed by decreasing the growing exposure of alerts. Initially it was thought that the reduction in the number of interactions could be achieved by only firing high severity alerts (20). Although this was thought to be a simple and direct approach to reduce alert fatigue and sensitivity, this study showed otherwise. For an example, it seems to be 'pain in the neck' for antiplatelet-anticoagulant combination. The physicians were attentive that co-prescriptions of antiplatelet and anticoagulants would raise the risk of bleeding episodes hence the alert is not going to alter standardized drug treatment protocol. In fact, there are guidelines on how to manage such elevated risk of bleeding and suggests that antiplatelet therapy should be co-prescribed with proton pump 
inhibitors (79). This was a classic example where not all PDDIs with high-risk alerts are relevant. This opens a higher chance to ignore and develop a habit to suspend the alerts without even reading it. While alerts can be lifesaving, flagging too many PDDIs are redundant, reminding physicians things they already know. To our surprise, physicians responded poorly even with just high severity PDDIs alerts. This gives an insight whose severity category was ambiguous needs an alteration in CDDSS. Indeed, the number of alerts is not an appropriate metric for the success or failure of CDDSS. The same was hypothesized in a previous study by Duke et al (21).

Fundamentally, CDDSS only allows the detection of 'potential' interactions which means the PDDIs may not manifest into an $A D E$ in all patients. This finding confirms the relationship between overridden alerts and ADE. First, a huge number of alerts were overridden, and ADE was not indicative (2957/3137; 94.3\%). Second, the tendency of physicians to suspend the alerts and caused ADE $(180 / 284 ; 63.4 \%)$. It is known that the proportion of PDDIs resulted in clinically relevant ADE including in this study (22). This reflects that justified override cannot always prevent an $\operatorname{ADE}(23)$, which translates as inappropriate overrode. Contrariwise, appropriate alerts can be overridden and that overriding may not necessarily cause ADE. Still and all, some patients may benefit from interacting with drug combinations because the additive effects may be necessary to adequately treat a disease or symptom. One sample of case study retrieved during the study period is presented here as an illustration of inappropriate override that subsidized for an ADE.

Case Study: A 69-year-old, woman developed shortness of breath associated with chest discomfort and was brought into the emergency department. Her past medical history included hypertension, diabetes mellitus type 2, ESRD and asthma. The patient is a known case of Non-ST elevation myocardial infarction and acute pulmonary edema with left ventricular ejection fractions of $35 \%$. On admission at CCU, she had a pulse of $99 \mathrm{bpm}$ (irregular), a respiratory rate of 27/min and blood pressure of 177/120 $\mathrm{mmHg}$ and was alert and conscious at CCU. She was on azithromycin $500 \mathrm{~g} \mathrm{bd} x 3$ days and ivabradine $7.5 \mathrm{mg}$ bd $\mathrm{x}$ daily. Ivabradine was prescribed for symptomatic angina and azithromycin for atypical pneumonia. An ECG showed sinus rhythm with a baseline QTc reading of 497 milliseconds. The serum potassium finding was on the higher side; $5.4 \mathrm{mEq} / \mathrm{L}$ while her other electrolytes range were normal. The physician discontinued potassium chloride. CDDSS: Alerted for potential QT interval prolongation with concomitant use of ivabradine - azithromycin. Clinical judgement: Day 1: The physician overrode the alert and responded to observe the adverse effects. Medications were continued. Day 2: She was hemodynamically unstable. An ECG showed QT interval prolonged with a QTc reading of 522 milliseconds. The physician discontinued azithromycin in view of prolonged QT interval. Sudden cardiac arrest during hemodialysis later of the day and successfully resuscitated. Physician discontinued ivabradine. Day 3: She was hemodynamically stable. An ECG showed sinus arrhythmia with improved QTc reading of 468 milliseconds. DIPS: Revealed highly probable DDIs.

\section{Recommendations}

Hospitals that plan for CDDSS implementation should consider avoiding overwhelming alerts and the possibility of overlooking the clinically significant alerts. An ideal alert should be tiered appropriately, 
instead of being sensitive it should be specific $(14,24)$. Alerts should be categorized as interruptive, noninterruptive (passive) or not shown at all alert. Alerts should be configurable specific to physician specialty, drug class to class interaction specific and adverse effect specific.

\section{Conclusion}

Skepticism about the usefulness of CDSS and the wariness about accepting the CDDSS are likely to be decreased if the occurrences of $A D E$ are made known. Understanding the relationship of appropriate alerts, overridden alerts and prevalence of ADE would identify alerts that are not so useful. CDDSS warned accurate alerts but did not substantially influence prophylactic tendencies. This is because appropriate alerts were superfluous and not useful in a clinical context. Review of the potential drug interaction alert that is produced at monthly audits, the management may decide to omit such insignificant interaction in future. There was a lack of agreement between the two CDDSS in the ability to detect the presence of potential interactions compromising true adverse drug interaction in the critical cardiac patients. Until adequately designed CDDSS are made available customized to the context of use, it appears that we may have to use both CDDSS applications to screen for PDDIs in patients' medication regimens.

\section{Declarations}

\section{Acknowledgements}

The authors thank all the cardiologists who treated the patients, staff nurses of the coronary care unit who took care of the patients during admission and the Clinical Research Department for facilitating the provision of the required information.

\section{Authorship}

AM: Wrote original manuscript, researched the topic, and collected data. AK, SN and H: Edited manuscript and supervised my work. H, NT, MI, AT, and SM: Assisted with the research and examined the patients.

\section{Compliance with ethical standards}

\section{Funding \& Ethical approval}

This study is a part of Master of Medical and Health Sciences project and was approved and funded by the Research and Ethics Committee of the IMU (404/2017) and IJN (IJNREC/250/2017). This study was conducted in full conformance with the principles of the Declaration of Helsinki, Good Clinical Practice, and within the laws and regulations of the country in which the research was conducted.

\section{Conflicts of interest}

Aminah Mazyin Mohamed Ariff, Sivalingam Nalliah, Hafidz Abd Hadi, Nay Thu Win, Mohamed Imran Thoulath, Subashini Muthiah Mutaya, Ahmad Tantawi Jauhari Aktifanus, and Ahmad K. M. Yusof have no 
relevant conflicts of interest to declare.

\section{Patient consent}

Data are anonymized. General informed consent for utilizing data for research purposes was obtained for all patients of the National Heart Institute (IJN), Kuala Lumpur, Malaysia.

\section{References}

1. Kannan B, Nagella AB, Sathia Prabhu A, Sasidharan GM, Ramesh AS, Madhugiri V. Incidence of Potential Drug-Drug Interactions in a Limited and Stereotyped Prescription Setting - Comparison of Two Free Online Pharmacopoeias. Cureus. 2016;8(11).

2. Zheng WY, Richardson LC, Li L, Day RO, Westbrook JI. Drug-drug interactions and their harmful effects in hospitalised patients: a systematic review and meta-analysis. Eur J Clin Pharmacol. 2017;

3. Glassman PA, Simon B, Belperio P, Lanto A. Improving recognition of drug interactions benefits and barriers to using automated drug alerts. Med Care. 2002;40(12):1161-71.

4. FBA Rahman, CAP Joring, JY Wen, CL Yii KA. Knowledge of Drug-drug Interactions among Pharmacy Department Staff in Miri General Hospital: A cross-sectional study. Sarawak J Pharm. 2019;29-45.

5. Classen DC, Bates DW. Finding the Meaning in Meaningful Use. 2011;855-8.

6. HIMSS. Health Information Management Systems Society. (2013). Dictionary of healthcare information technology terms, acronyms, and organizations, third ed. P.33. ISBN: 978-1-938904-28-8. 2013.

7. Radley DC, Wasserman MR, Olsho LEW, Shoemaker SJ, Spranca MD, Bradshaw B. Reduction in medication errors in hospitals due to adoption of computerized provider order entry systems. J Am Med Informatics Assoc. 2013;20(3):470-6.

8. Tragni E, Casula M, Pieri V, Favato G, Marcobelli A, Trotta MG, et al. Prevalence of the Prescription of Potentially Interacting Drugs. PLoS One. 2013;8(10):1-9.

9. Esmaeilzadeh P, Sambasivan M, Kumar N, Nezakati H. Adoption of clinical decision support systems in a developing country: Antecedents and outcomes of physician's threat to perceived professional autonomy. Int J Med Inform. 2015;84(8):548-60.

10. Winters BD, Cvach MM, Bonafide CP, Hu X, Konkani A, O'Connor MF, et al. Technological Distractions (Part 2): A Summary of Approaches to Manage Clinical Alarms with Intent to Reduce Alarm Fatigue. Crit Care Med. 2018;46(1):130-7.

11. Kane-Gill SL, O'Connor MF, Rothschild JM, Selby NM, McLean B, Bonafide CP, et al. Technologic Distractions (Part 1): Summary of Approaches to Manage Alert Quantity with Intent to Reduce Alert Fatigue and Suggestions for Alert Fatigue Metrics. Crit Care Med. 2017;45(9):1481-8.

12. Thomas BR, TJ C, Sabu N, ES L, Baby N, K M, et al. Prescribing Pattern of Cardiovascular Drugs - A Prospective Observational Study. Indian J Pharm Pract. 2018;10(4):287-92. 
13. Ahn EK, Cho SY, Shin D, Jang C, Park RW. Differences of reasons for alert overrides on contraindicated co-prescriptions by admitting department. Healthc Inform Res. 2014;20(4):280-7.

14. Rehr CA, Wong A, Seger DL, Bates DW. Determining inappropriate medication alerts from "inaccurate warning" overrides in the intensive care unit. Appl Clin Inform. 2018;9(2):268-74.

15. Horn JR, Hansten PD, Chan LN. Proposal for a new tool to evaluate drug interaction cases. Ann Pharmacother. 2007;41(4):674-80.

16. Gonzaga de Andrade Santos TN, Mendonça da Cruz Macieira G, Cardoso Sodré Alves BM, Onozato T, Cunha Cardoso G, Ferreira Nascimento MT, et al. Prevalence of clinically manifested drug interactions in hospitalized patients: A systematic review and meta-analysis. PLoS One. 2020;15(7):e0235353.

17. Janković SM, Pejčić A V., Milosavljević MN, Opančina VD, Pešić N V., Nedeljković TT, et al. Risk factors for potential drug-drug interactions in intensive care unit patients. J Crit Care. 2018;43:1-6.

18. A.Wong, M.G.Amato, D.L.Seger, C.Rehr, A.Wright, S.P.Slight, et al. Prospective evaluation of medication-related clinical decision support overrides in the intensive care unit. BMJ Qual Saf. 2018;27(9):718-24.

19. Nanji KC, Slight SP, Seger DL, Cho I, Fiskio JM, Redden LM, et al. Overrides of medication-related clinical decision support alerts in outpatients. J Am Med Informatics Assoc. 2014;21(3):487-91.

20. Alotaibi YK, Federico F. The impact of health information technology on patient safety. Saudi Med J. 2017;38(12):1173-80.

21. Duke Dr. JD, Li X, Dexter P. Adherence to drug-drug interaction alerts in highrisk patients: A trial of context-enhanced alerting. J Am Med Informatics Assoc. 2013;20(3):494-8.

22. Dumbreck S, Flynn A, Nairn M, Wilson M, Treweek S, Mercer SW, et al. Drug-disease and drug-drug interactions: Systematic examination of recommendations in $12 \mathrm{UK}$ national clinical guidelines. BMJ. 2015;350:1-8.

23. Alther M, Reddy CK. Clinical decision support systems. Healthcare Data Analytics. 2015. 625-656 p.

24. Wright A, McEvoy DS, Aaron S, McCoy AB, Amato MG, Kim H, et al. Structured override reasons for drug-drug interaction alerts in electronic health records. J Am Med Informatics Assoc. 2019;26(April):934-42.

\section{Tables}

Table 1

Override rate by category

\begin{tabular}{|lll|}
\hline Alert overrides by category & $\mathbf{n = 3 1 3 7}$ & $\%$ \\
\hline Alert overridden, ADE observed and action taken & 132 & 4.2 \\
\hline Alert overridden, ADE observed but no action taken & 48 & 1.5 \\
\hline Alert overridden and ADE not observed & 2957 & 94.3 \\
\hline
\end{tabular}


Table 2

Override reasons by drugs

\begin{tabular}{|c|c|c|c|c|}
\hline \multirow[t]{2}{*}{ Override reasons } & \multirow[t]{2}{*}{$\begin{array}{l}\text { Potential drug to drug } \\
\text { interactions alert }\end{array}$} & \multicolumn{2}{|c|}{$\begin{array}{l}\text { Override } \\
\text { rate }\end{array}$} & \multirow[t]{2}{*}{$\begin{array}{l}\mathrm{p} \\
\text { value* }\end{array}$} \\
\hline & & $\mathbf{n}$ & $\%$ & \\
\hline \multirow[t]{5}{*}{ Patient will be observed for adverse effects (651) } & $\begin{array}{l}\text { Potassium chloride -- } \\
\text { spironolactone }\end{array}$ & 26 & 4 & $>0.05$ \\
\hline & $\begin{array}{l}\text { Potassium chloride -- } \\
\text { perindopril }\end{array}$ & 25 & 3.8 & \\
\hline & $\begin{array}{l}\text { Amiodarone - } \\
\text { Furosemide }\end{array}$ & 39 & 6 & \\
\hline & Digoxin -- Bisoprolol & 13 & 2 & \\
\hline & $\begin{array}{l}\text { Potassium chloride -- } \\
\text { spironolactone }\end{array}$ & 18 & 2.8 & \\
\hline \multirow[t]{5}{*}{ Treatment plan requirement (840) } & Aspirin -- Clopidogrel & 112 & 13.3 & $<.001$ \\
\hline & $\begin{array}{l}\text { Fondaparinux - } \\
\text { Ticagrelor }\end{array}$ & 44 & 5.2 & \\
\hline & Midazolam -- Fentanyl & 61 & 7.3 & \\
\hline & $\begin{array}{l}\text { Atorvastatin - } \\
\text { Clopidogrel }\end{array}$ & 77 & 9.2 & \\
\hline & Aspirin -- Amlodipine & 36 & 4.3 & \\
\hline \multirow[t]{5}{*}{ Benefit outweighs the risk (528) } & Aspirin -- Furosemide & 109 & 20.6 & $>0.05$ \\
\hline & $\begin{array}{l}\text { Clopidogrel -- } \\
\text { Esomeprazole }\end{array}$ & 31 & 5.9 & \\
\hline & $\begin{array}{l}\text { Amiodarone - } \\
\text { Bisoprolol }\end{array}$ & 18 & 3.4 & \\
\hline & Aspirin -- Perindopril & 48 & 9.1 & \\
\hline & $\begin{array}{l}\text { Esomeprazole -- } \\
\text { Furosemide }\end{array}$ & 51 & 9.7 & \\
\hline \multirow[t]{4}{*}{ Clinically insignificant (352) } & Aspirin -- Heparin & 71 & 20.2 & $>0.05$ \\
\hline & Bisoprolol -- Lidocaine & 75 & 21.3 & \\
\hline & $\begin{array}{l}\text { Amiodarone - } \\
\text { Lidocaine }\end{array}$ & 16 & 4.5 & \\
\hline & Enoxaparin -- Heparin & 4 & 1.1 & \\
\hline
\end{tabular}

*Significant at $p<0.05$ 


\begin{tabular}{|c|c|c|c|c|}
\hline & $\begin{array}{l}\text { Lidocaine - } \\
\text { Rocuronium }\end{array}$ & 13 & 3.7 & \\
\hline \multirow[t]{5}{*}{ Patient tolerated combination before (658) } & $\begin{array}{l}\text { Clopidogrel -- } \\
\text { Ticagrelor }\end{array}$ & 19 & 2.9 & $>0.05$ \\
\hline & Aspirin - Insulin & 72 & 11.1 & \\
\hline & Bisoprolol - Insulin & 43 & 6.6 & \\
\hline & Aspirin -- Perindopril & 33 & 5.1 & \\
\hline & $\begin{array}{l}\text { Atorvastatin - } \\
\text { Clopidogrel }\end{array}$ & 17 & 2.6 & \\
\hline \multirow{4}{*}{$\begin{array}{l}\text { Adverse effect can be prevented with proper } \\
\text { dosing, time or route of administration (108) }\end{array}$} & Aspirin - Perindopril & 7 & 6.5 & $>0.05$ \\
\hline & $\begin{array}{l}\text { Calcium Gluconate - } \\
\text { Ceftriaxone }\end{array}$ & 14 & 13 & \\
\hline & $\begin{array}{l}\text { Insulin - } \\
\text { Hydrocortisone }\end{array}$ & 8 & 7.4 & \\
\hline & $\begin{array}{l}\text { Levothyroxine - } \\
\text { Ferrous Fumarate }\end{array}$ & 5 & 4.6 & \\
\hline
\end{tabular}

Table 3

Accepted rate by category

\begin{tabular}{|lll|}
\hline Accepted Category & $\mathbf{n = 1 4 7}$ & $\mathbf{\%}$ \\
\hline ADE occurred before warranting the doctor and action taken & 104 & 70.7 \\
\hline Alert accepted and ADE did not occur & 43 & 29.3 \\
\hline
\end{tabular}


Table 4

Causation of alert overrides, ADE, and actions

\begin{tabular}{|c|c|c|c|c|c|}
\hline $\begin{array}{l}\text { Adverse drug to drug } \\
\text { interactions }\end{array}$ & $\begin{array}{l}\text { Clinical } \\
\text { adverse effect }\end{array}$ & Micromedex & MIMS & $\begin{array}{l}\text { Reasons } \\
\text { for } \\
\text { overrides }\end{array}$ & $\begin{array}{l}\text { Post-ADE } \\
\text { action }\end{array}$ \\
\hline \multirow[t]{3}{*}{$\begin{array}{l}\text { amiodarone - } \\
\text { furosemide (9) }\end{array}$} & \multirow[t]{3}{*}{ Prolonged QT } & \multirow[t]{3}{*}{$\mathrm{N} / \mathrm{A}$} & \multirow[t]{3}{*}{ Major } & $\begin{array}{l}\text { Will } \\
\text { observe for } \\
\text { adverse } \\
\text { effect (6) }\end{array}$ & $\begin{array}{l}\text { Discontinue } \\
\text { medication } \\
\text { (6) }\end{array}$ \\
\hline & & & & $\begin{array}{l}\text { Treatment } \\
\text { plan } \\
\text { requirement } \\
(1)\end{array}$ & $\begin{array}{l}\text { Change } \\
\text { ROA (2) }\end{array}$ \\
\hline & & & & $\begin{array}{l}\text { Benefit } \\
\text { outweighs } \\
\text { the risk (2) }\end{array}$ & $\begin{array}{l}\text { Administer } \\
\text { antidote (1) }\end{array}$ \\
\hline $\begin{array}{l}\text { amiodarone - colchicine } \\
\text { (1) }\end{array}$ & $\begin{array}{l}\text { Ventricular } \\
\text { arrhythmia }\end{array}$ & $\mathrm{N} / \mathrm{A}$ & Major & $\begin{array}{l}\text { Benefit } \\
\text { outweighs } \\
\text { the risk (1) }\end{array}$ & $\begin{array}{l}\text { Discontinue } \\
\text { medication } \\
\text { (1) }\end{array}$ \\
\hline \multirow[t]{2}{*}{$\begin{array}{l}\text { amiodarone - } \\
\text { vasopressin (2) }\end{array}$} & \multirow[t]{2}{*}{ Prolonged QT } & \multirow[t]{2}{*}{ Major } & \multirow[t]{2}{*}{$\mathrm{N} / \mathrm{A}$} & $\begin{array}{l}\text { Observe for } \\
\text { adverse } \\
\text { effects (1) }\end{array}$ & $\begin{array}{l}\text { Discontinue } \\
\text { medication } \\
\text { (1) }\end{array}$ \\
\hline & & & & $\begin{array}{l}\text { Treatment } \\
\text { plan } \\
\text { requirement } \\
(1)\end{array}$ & $\begin{array}{l}\text { Administer } \\
\text { antidote (1) }\end{array}$ \\
\hline $\begin{array}{l}\text { azithromycin - } \\
\text { ivabradine (1) }\end{array}$ & Prolonged QT & Major & Major & $\begin{array}{l}\text { Observe for } \\
\text { adverse } \\
\text { effects (1) }\end{array}$ & $\begin{array}{l}\text { Discontinue } \\
\text { medication } \\
\text { (1) }\end{array}$ \\
\hline \multirow[t]{3}{*}{ aspirin - furosemide (4) } & \multirow[t]{3}{*}{ Nephrotoxicity } & \multirow[t]{3}{*}{ Major } & \multirow[t]{3}{*}{ Moderate } & $\begin{array}{l}\text { Observe for } \\
\text { adverse } \\
\text { effects (1) }\end{array}$ & \multirow[t]{3}{*}{$\begin{array}{l}\text { Discontinue } \\
\text { medication } \\
\text { (4) }\end{array}$} \\
\hline & & & & $\begin{array}{l}\text { Treatment } \\
\text { plan } \\
\text { requirement } \\
\text { (2) }\end{array}$ & \\
\hline & & & & $\begin{array}{l}\text { Benefit } \\
\text { outweighs } \\
\text { the risk (1) }\end{array}$ & \\
\hline digoxin -- furosemide (4) & $\begin{array}{l}\text { Digoxin } \\
\text { Toxicity/ } \\
\text { Arrhythmia/ }\end{array}$ & Moderate & Major & $\begin{array}{l}\text { Benefit } \\
\text { outweighs } \\
\text { the risk (1) }\end{array}$ & $\begin{array}{l}\text { Discontinue } \\
\text { medication } \\
\text { (3) }\end{array}$ \\
\hline
\end{tabular}




\begin{tabular}{|c|c|c|c|c|c|}
\hline $\begin{array}{l}\text { Adverse drug to drug } \\
\text { interactions }\end{array}$ & $\begin{array}{l}\text { Clinical } \\
\text { adverse effect }\end{array}$ & Micromedex & MIMS & $\begin{array}{l}\text { Reasons } \\
\text { for } \\
\text { overrides }\end{array}$ & $\begin{array}{l}\text { Post-ADE } \\
\text { action }\end{array}$ \\
\hline & & & & $\begin{array}{l}\text { Treatment } \\
\text { plan } \\
\text { requirement } \\
\text { (1) observe } \\
\text { for adverse } \\
\text { effects (2) }\end{array}$ & $\begin{array}{l}\text { Change } \\
\text { ROA, } \\
\text { dosage, } \\
\text { frequency, } \\
\text { time } \\
\text { interval (1) }\end{array}$ \\
\hline $\begin{array}{l}\text { amiodarone - bisoprolol } \\
(2)\end{array}$ & $\begin{array}{l}\text { Hypotension/ } \\
\text { Bradycardia/ } \\
\text { Arrhythmia }\end{array}$ & Moderate & Major & $\begin{array}{l}\text { Will } \\
\text { observe for } \\
\text { adverse } \\
\text { effect (2) }\end{array}$ & $\begin{array}{l}\text { Discontinue } \\
\text { medication } \\
\text { (2) }\end{array}$ \\
\hline $\begin{array}{l}\text { piperacillin/tazobactam - } \\
\text { - warfarin (1) }\end{array}$ & Bleeding & Major & Moderate & $\begin{array}{l}\text { Treatment } \\
\text { plan } \\
\text { requirement } \\
(1)\end{array}$ & $\begin{array}{l}\text { Discontinue } \\
\text { medication } \\
\text { (1) }\end{array}$ \\
\hline $\begin{array}{l}\text { furosemide - haloperidol } \\
\text { (1) }\end{array}$ & $\begin{array}{l}\text { Electrolyte } \\
\text { disturbances } \\
\& T d P\end{array}$ & N/A & Major & $\begin{array}{l}\text { Observe for } \\
\text { adverse } \\
\text { effects (1) }\end{array}$ & $\begin{array}{l}\text { Discontinue } \\
\text { medication } \\
\text { (1) }\end{array}$ \\
\hline $\begin{array}{l}\text { aspirin - fondaparinux } \\
\text { (4) }\end{array}$ & Bleeding & Major & Moderate & $\begin{array}{l}\text { Treatment } \\
\text { plan } \\
\text { requirement } \\
(4)\end{array}$ & $\begin{array}{l}\text { Discontinue } \\
\text { medication } \\
\text { (4) }\end{array}$ \\
\hline
\end{tabular}

\section{Figures}




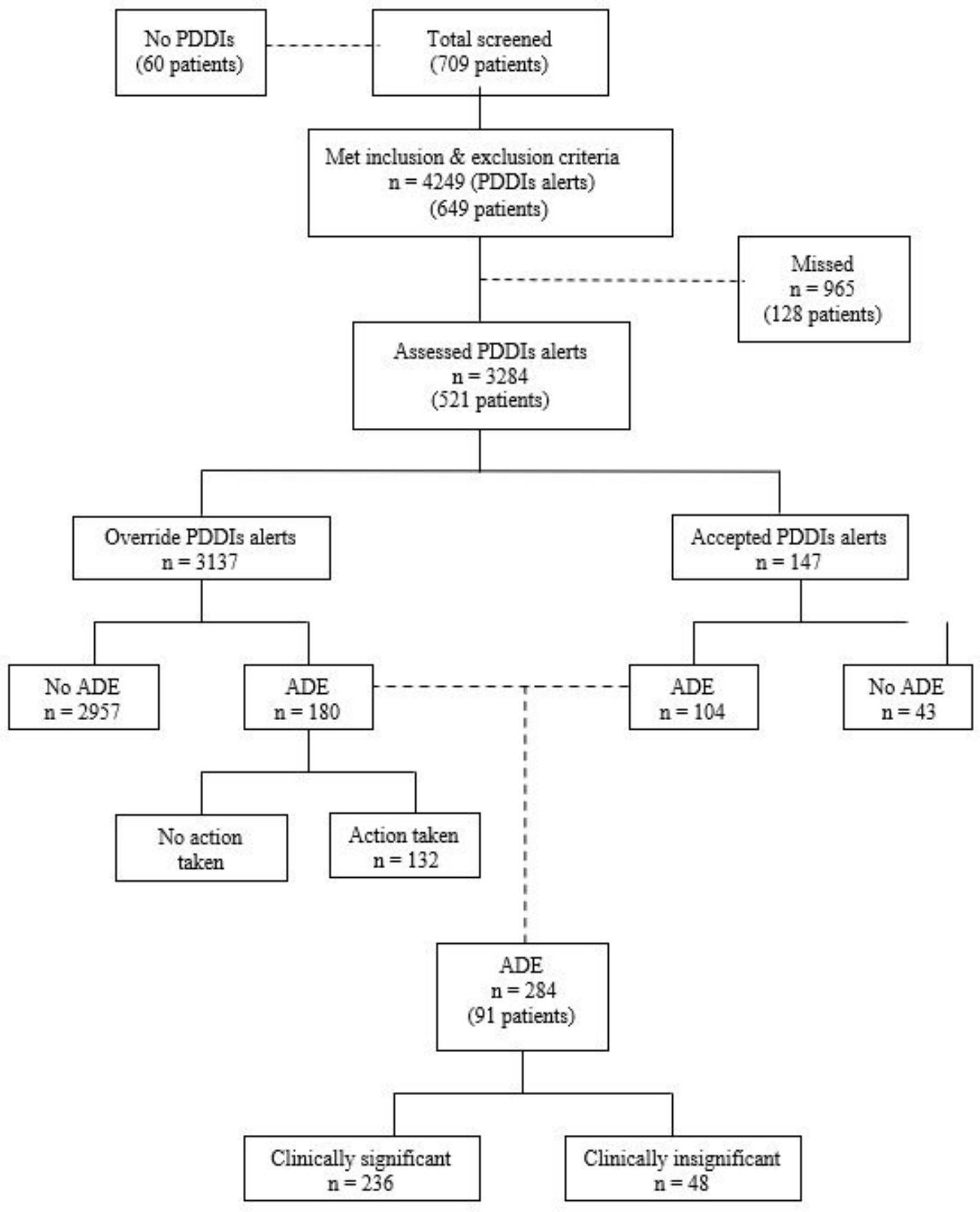

Figure 1

Recruitment methodology

\section{Supplementary Files}

This is a list of supplementary files associated with this preprint. Click to download.

- SupplementalFile1.pdf 